\title{
Assessing the Implementation of the Energy Management System in the First ISO 50001 Building in Indonesia
}

\author{
Robi Kurniawan ${ }^{1, *}$, Agung Feinnudin ${ }^{1}$ \\ ${ }^{1}$ Ministry of Energy and Mineral Resources, Jl. Medan Merdeka Selatan No. 18, DKI Jakarta 10110, \\ Indonesia
}

Received 2 August 2021; Accepted 30 August 2021

Available online 31 August 2021

\begin{abstract}
This study focuses on the public building in Indonesia that has implemented an energy management system compliant with ISO 50001 standard. The main objectives of this study are to review the implementation of the energy management system in the building, highlighting the main aspect of the ISO cycle deployment and key lessons learned for further dissemination. We performed the study of the implementation of energy management in the building sector based on the ISO 50001 framework that aims to enhance an organization to pursue the continuous improvement of energy management with a systematic approach. Implementing the plan, do, check and act cycle of the ISO's framework, it is found that the management keeps a strong commitment to continuous improvement. As part of the energy management system cycle, an Investment Grade Audit (IGA) was performed in 2018. Implementing the IGA recommendation, both passive and active designs have been applied in the Slamet Bratanata building. Active design strategies that have been implemented include building automation system utilization, chiller and lighting replacement and Energy Monitoring System (EMonS) application. Implemented passive designs include windows film installation and an efficient room redesigned for optimizing natural light. To implement the ISO 50001 Energy Management System in the building, the energy management team has also held various activities. It includes developing Standard Operating Procedures, appointing a Person in Charge on each floor, conducting capacity building and performing an energy efficiency campaign. It is estimated that the energy management system has succeeded in reducing energy consumption by $613.188 \mathrm{kWh}$ (in 2018-2020) and the Energy Efficiency Index by $129.06 \mathrm{kWh} / \mathrm{m}^{2} /$ year in 2020 . Furthermore, management energy implementation also reduced greenhouse gas emissions by 539.60 tons of $\mathrm{CO}_{2}$ equivalent. This study provides a reference for energy management in another building for improving its energy performance.
\end{abstract}

Keywords: energy efficiency, energy management system, building sector, ISO 50001, energy security

\section{Introduction}

Energy efficiency measures have a significant contribution toward energy security improvement. It is considered an effective and low-cost strategy for strengthening the country's energy security by reducing energy demand and minimizing import dependency (Trotta, 2020). Furthermore, it improves security from an environmental perspective, such as by reducing local energy pollution and climate change mitigation (Selvakkumaran \& Limmeechokchai, 2013). Even in the current situation, some energy efficiency measures, such as the building sector, impact both pandemic economic recovery and climate action (Hepburn et al., 2020).

The building sector contributes the lion's share of the total energy consumption. Globally, the sector consumes $30 \%$ of the world's final energy consumption, representing $28 \%$ of energy-related $\mathrm{CO}_{2}$ emissions (IEA, 2019). Since the COVID-19 pandemic only contributed to temporary emission change, a proper measure is necessary to mitigate the effect over the long term (Forster et al., 2020). To reduce energy consumption and improve environmental sustainability, energy efficiency in buildings has a crucial role (Shaikh et al., 2017). Having a short and long-term impact, building energy retrofit is one

*Corresponding author

E-mail address: kurniawan.tohoku@gmail.com 
of the recommended actions for achieving sustainable recovery (Halimatussadiah et al., 2020) and an important pillar of energy transition (IEA, 2021).

In an emerging country such as Indonesia, increasing urbanization triggers energy use in the building sector. Fulfilling fossil sources (Mardiana et al., 2018; Purnomo Yusgiantoro Center, 2021), energy consumption in the country has increased significantly (Kurniawan et al., 2020). In Indonesia, the public sector and commercial and hotel dominate the energy consumption in the building sector, according to a survey conducted by the Directorate General of New Renewable Energy and Energy Conservation (EBTKE, 2019). Therefore, the energy consumption and emission reduction targets entail considerable effort in promoting and implementing an energy management system in the public building sector.

Several actions, including technological solutions, rigorous policies, and systems and practices, can effectively minimize building energy consumption (Zhou et al., 2018). The behaviour of the occupants influences energy consumption significantly in the building sector (Jia et al., 2017). In addition, the daily energy consumption in buildings is related to energy loads (Molina-Solana et al., 2017). From several measure options, it is found that the implementation of energy management systems is considered the most efficient measure in the building sector (Zheng et al., 2018).

The deployment of ISO 50001 is highly effective for energy management systems in the building sector (Ferrari et al., 2020). The ISO 50001 standard defines the requirements to develop, initiate, maintain and improve the energy management system. This ISO aims to enhance an organization's continuous improvement of energy management with a systematic approach. The standard identifies the requirements of energy management systems, including energy efficiency, consumption and use, by providing a specific guideline. It covers the plan, do, check and act cycle. In Indonesia, it is used increasingly, especially in industrial sectors. However, the building sector has applied it poorly. In 2020, only two-building, out of 113 objects, have implemented the certification.

Our study focuses on the first Indonesian public building that has implemented an energy management system compliant with ISO 50001. Having the opportunity in strengthening energy security, only a few buildings implemented such standards. The object of the study is the first implemented in terms of ministerial building. The objective of the present study is to describe the approach adopted for the energy management systems of the building, highlighting the main aspects that determined this interesting and unique experience. The result of the study can contribute significantly to more effective energy management as a reference for the further desirable implementation of ISO 50001 Standard in a similar public building and building sector contexts.

The structure of this study unfolds as follows: Section 2 delivers the framework and methodology, the result and discussion are presented in Section 3, while Section 4 concludes by summarizing key messages prompted by our findings.

\section{Framework and Case Study Overview}

\subsection{ISO 50001 Framework}

To comply with ISO 50001 standard, several parameters are audited to measure and check the impact of any act implemented on the system. It primarily includes organizational context, leadership, energy planning, supporting system, operations, performance evaluation and improvements (Ferrari et al., 2020; Huang, 2011; SGS, 2017). Organizational perspective should serve as a high-level framework understanding of issues that can have impact on energy performance and energy management systems of the organization. Furthermore, the definition of organization objective for improving energy performance should be declared formally. In the ISO standard, top management that directs and controls the organization has significant roles (Ferrari et al., 2020). It covers:

- ensuring the energy policy is suitable with the proportion of the utilization and consumption of energy in the organization

- covering commitment for complying with regulations related to energy utilization; 
- pledging to implement continuous improvement of the energy performance;

- providing specific framework for determining and assessing energy targets;

- supporting necessary planning, budgeting and purchasing for energy performance improvement;

- including commitment to provide necessary resources and information to achieving determined aim and target;

- conducting regular assessment necessary progress;

- communicating and documenting information to all organization levels.

Concerning energy planning, the organization should focus on energy performance and its supporting activities. Energy planning should cover some primary elements, such as strategies, technical evaluation and economic feasibility of the measure. For conducting this, the supporting system and operation should be checked. A supportive system is required to assist the energy planning performed by an effective management system. This system will also be related to the operation, especially in dealing with significant energy use and implementing the action plan. Having this, the organization may bridge the energy management, the performance activities and the organizations' business process.

To comply with the standard, performance evaluations followed by improvement also play a crucial role. Performance evaluation requires rigorous monitoring, measurement and evaluation of the overall energy performance. It is conducted by an effective data collection in the energy management system framework. By analysing the parameters, improvements activities can be performed. It is intended to discover a new opportunity for enhancing the energy performance of the organization.

\subsection{Implementation of ISO 50001 Standard for Energy Management System}

We structure our analysis of implementing the first ISO 50001 in the building sector based on the ISO 50001 framework as indicated in Figure 1. A particular approach was also employed in assessing the implementation of energy management systems in the building sector (Ferrari et al., 2020). The recursive process of ISO 50001 aims to improve the energy management system continuously. It covers the plan, do, check and act cycle adapted to the energy management systems implemented in the public building.

To conduct an energy management system, the organization should have an energy policy that describes the adopted general strategies. Formulating the strategies should involve the entire organization, including a communication strategy for improving staff's capacity. Energy planning activity establishes aims and processes needed to achieve output following the specific energy policy of the organization. In this energy planning stage, energy consumption in the object is analysed by implementing an energy audit. By doing the audit, consumption profile and opportunity improvement can be understood. This step is also necessary for measuring the baseline of some key performance. indicators. Implementation of the plan as an output from the energy is scheduled for a certain period by also considering the technoeconomic condition from the building management.

Check activity is evaluated by monitoring and measuring processes parallel with the aims, energy policy and goals set in the beginning. This activity is also crucial for understanding if the energy management system has been correctly performed according to the ISO 50001 standard. This activity also produces the necessary report, as well as solving and managing any nonconformities. Lastly, the act process refers to continuous improvement of the energy management of the organization. 


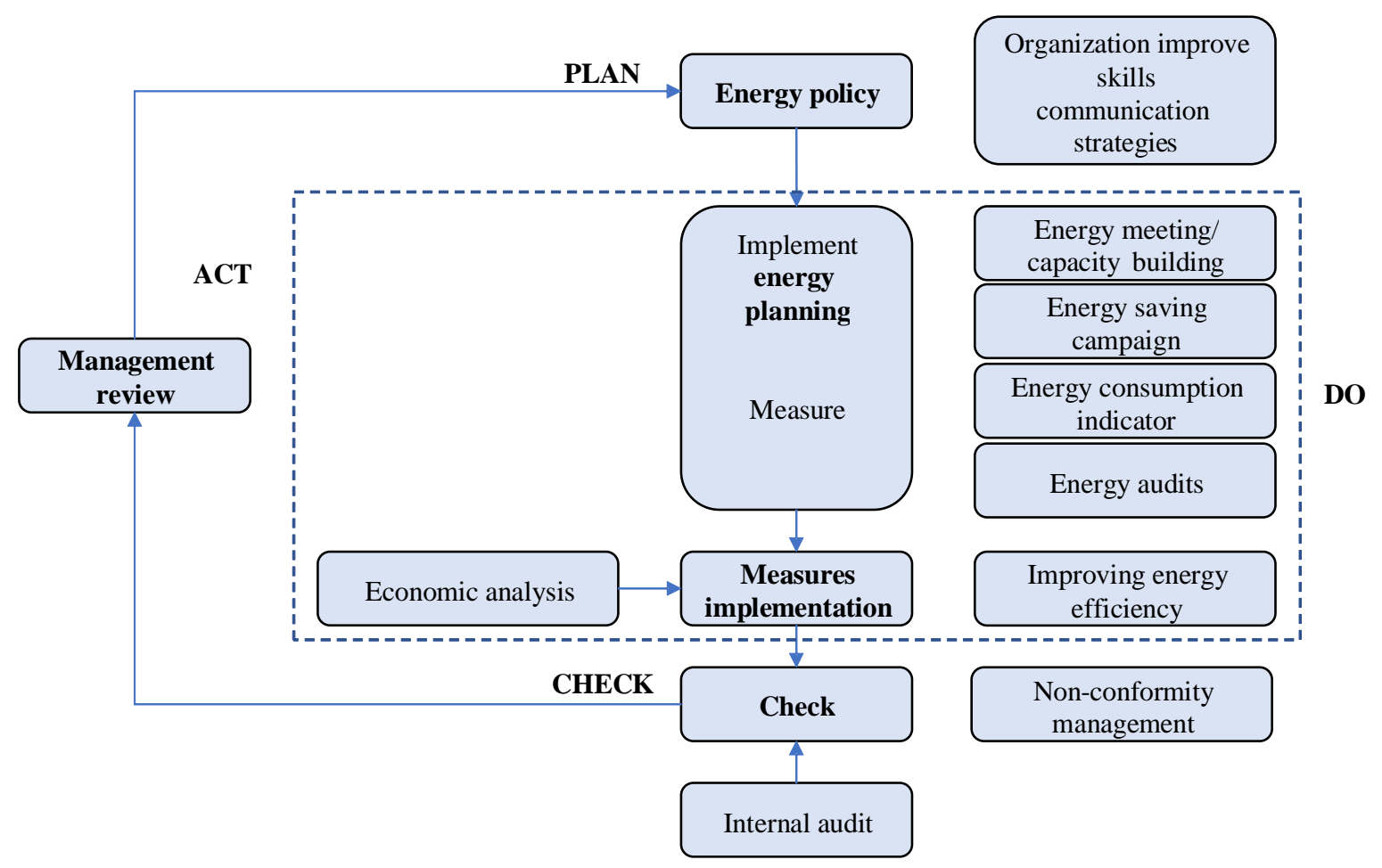

Figure 1. Implementation of energy management system complied with ISO 50001 standard.

\subsection{Building overview}

To perform an effective energy management system in a large building, it is necessary to understand the basic information of the building such as floor area, primary energy supply and consumption profile. The Slamet Bratanata is a public building owned by the Ministry of Energy and Mineral Resources, Indonesia. The office building consists of eight floors and two basements with a gross floor area of $12,299 \mathrm{~m}^{2}$ and has been established for 27 years. It is the first ministerial government building in Indonesia certified Energy Management System standard ISO 50001: 2018.

Electricity is mainly supplied by PLN, a public utility company in Indonesia, and rooftop photovoltaic $(\mathrm{PV})$. This rooftop PV has 26,000 Wp capacity, approximately $98.8 \mathrm{kWh} /$ day. Most of the electricity produced by rooftop PV, around $78 \%$, is used for the lighting system in the basement area and air conditioning system in the Uninterruptible Power Supplies (UPS) area. On average, the energy savings obtained from this rooftop PV reaches $28,032 \mathrm{kWh} /$ year.

From the demand side, energy consumption in the Slamet Bratanata is divided into several systems, as indicated in Figure 2. It includes air conditioning systems, lighting and plug load systems, fans, elevator and pumps systems. The proportion of the system consumption is presented in Figure 2. Air conditioning systems have the lion's share of building energy consumption. It consumes around $77 \%$ of the total building energy consumption. The combined energy consumption for lighting and plug loads contributes $13 \%$ of the total energy consumption. Therefore, reducing energy consumption for air conditioning systems and lighting through passive design and active design will significantly reduce the overall energy consumption of the building. 


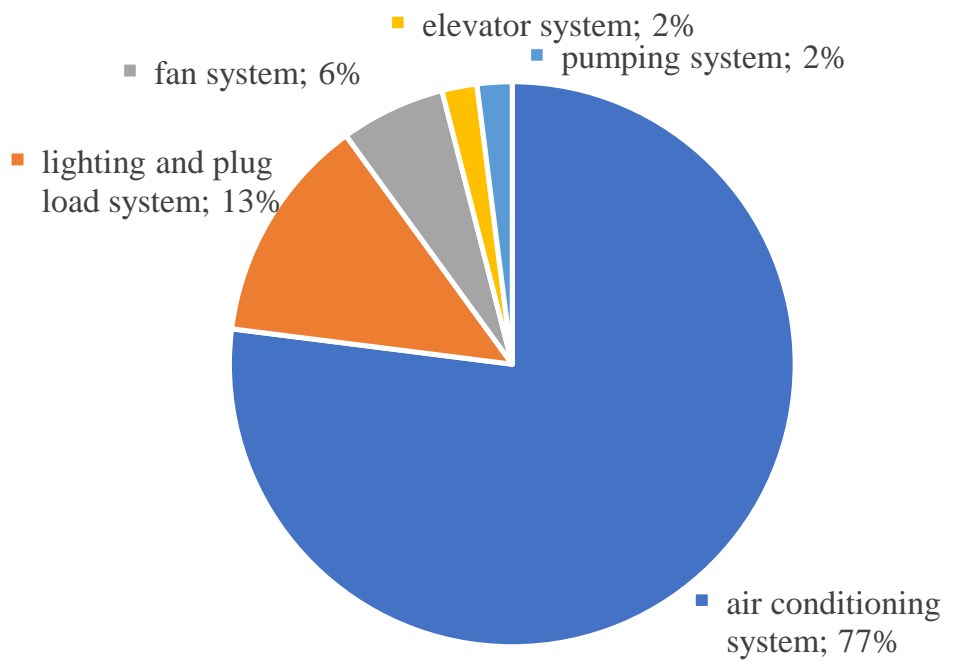

Figure 2. Energy use share.

\section{Result and discussion}

Concerning the general energy policy cycle, the top management goal is to ensure the Slamet Bratanata building becomes a role model in international standardized energy management in the building sector, especially in a government building. The top-level management of the building commits to implement an energy management system through ISO 50001: 2018. As a form of participation and leadership commitment to energy savings, a Decree on the Establishment of the Energy Management organizational structure was established. In July 2019, the ISO 50001 implementation plan was launched as a form of high commitment from the top management on energy-saving programs in the Slamet Bratanata. Indeed, a sustained and robust commitment to top policies of building energy efficiency is one of the essential aspects of a successful energy efficiency project for its public building sector (Ma et al., 2019). As part of the commitment, the organizational structure was established for implementing the energy management system, as presented in Figure 3.

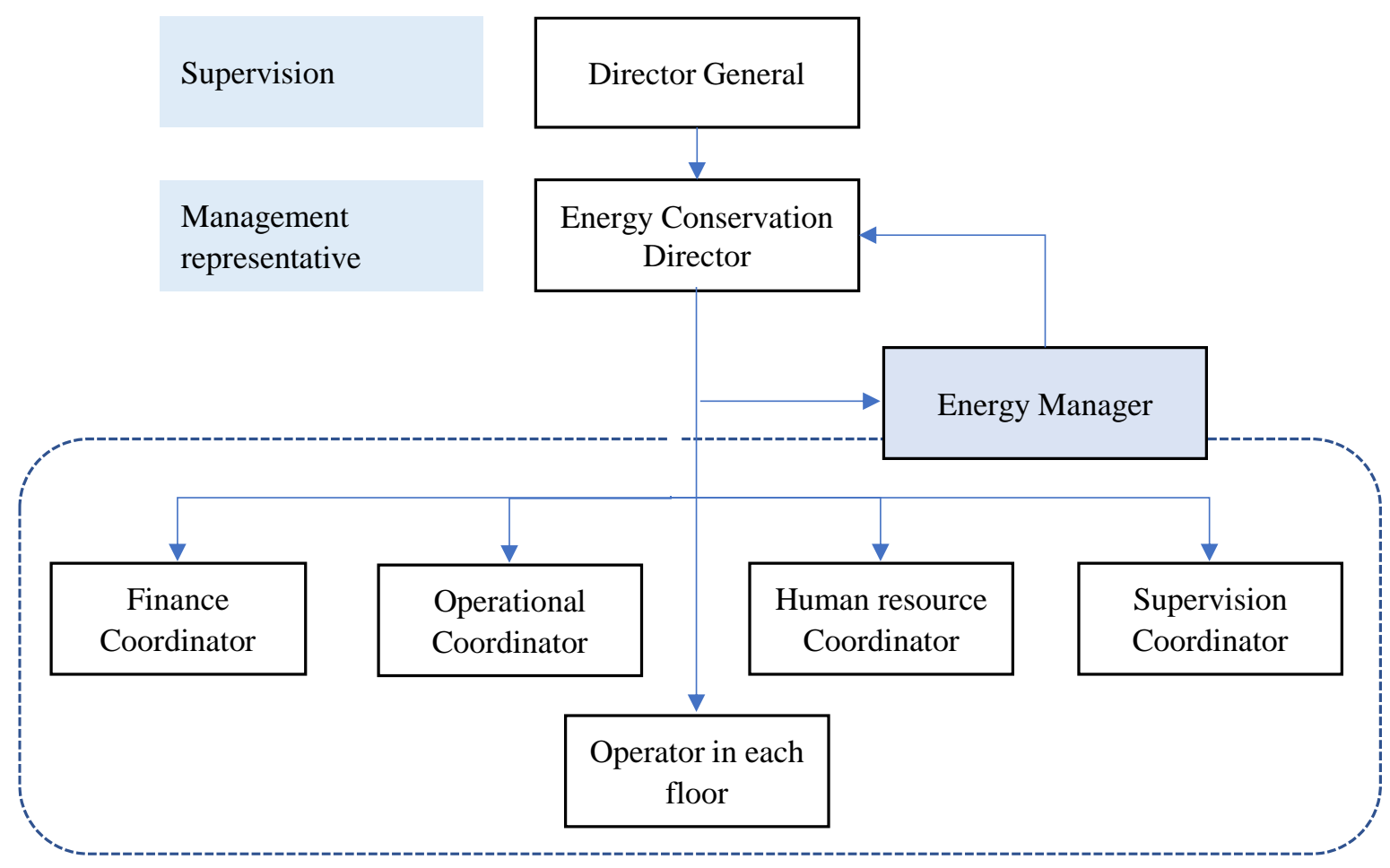

Figure 3. Energy management systems structure organization. 
Concerning resource management, the energy manager of the Slamet Bratanata has appointed a person in charge on each floor to oversee energy management activities. Having eight floors, the person has important roles such as ensuring each employee turns off all the devices when leaving the offices, fulfilling a $\log$ form of lightings, the standard temperature of air conditioning, computers and printers. There is an energy efficiency competition called "Lomba Hemat Energi" to cultivate energy efficiency habits on each floor every two years.

The energy management team has held various activities to implement ISO 50001 Energy Management System in the Slamet Bratanata. Standard Operational Procedure (SOP) for energy and water-saving in the building was established. Accordingly, as a derivation of the SOP, Working Instruction (WI) is used to document and implement ISO 50001:2018 Energy Management Systems. Working instruction was developed and implemented for all energy utilization, such as in air conditioning systems, lifts, lamps, pumps and other appliances. For instance, establishing a procedure to start the operation of AC system 0.5 hours before office hours and stop the operation of AC System 0.5 hours before the end of office hours. During the busy time ( 8 a.m. -9 a.m.; 4 p.m. -5 p.m.), all the elevators (five units) are turned on. The other times only half of the capacity is turned on. The working instructions have campaigned on each floor at a strategic place. Campaigns and socialization of energy and water savings by using banners, posters, stickers, video monitors and social media of the Slamet Bratanata were conducted. Putting in a strategic location, it can be read by all employees. The particular activity was deployed as part of the action to optimize energy and water usage.

As part of the energy management system cycle, Investment Grade Audit was performed in 2018. An energy audit that is conducted periodically is a suitable strategy to optimize energy consumption in the buildings sector (García-Sanz-Calcedo et al., 2018). According to the IGA document, several measures were recommended by the audit, as presented in Table 1 . It includes window film installation at $1^{\text {st }}-3^{\text {rd }}$ floor, installation of Building Automation System (BAS), replacing old chiller with mini chiller, equipped with Variable Refrigerant Flow (VRF) technology at $6^{\text {th }}$ floor, replacing lighting system with LED (762 lamps) and meeting room renovation for improving energy consumption. The estimated payback period for passive design is 5.8 years. While installing BAS, replacing the old chiller with VRF technology has a 5.5 years payback period estimation. Replacing the lamp with LED technology has the fastest payback period (2 years).

The top management of the Slamet Bratanata commits to save and reduce energy consumption by allocating budget to replace inefficient equipment as recommended by the previous Investment Grade Audit. Following the recommendation, the measures were carried out by management for the 20182020 fiscal year.

Implementing the IGA recommendation as presented in Table 1, some energy-efficient technologies have been applied in the Slamet Bratanata building. For supporting energy efficiency in office space, some action has been performed, including the passive design. In addition to windows film installation, the meeting rooms have been designed for natural lighting optimization. Using specific wall paint that follows the saving energy principle, the wall is painted using bright colors to optimize light density. Integration of passive design can significantly reduce the heating (Harkouss et al., 2018). Therefore, it should be utilized on a macro scale for reducing energy consumption (Sun et al., 2018). Table 1 indicated that saving from the window film installation has a low proportion compared to another measure. It is related to the application of the activity that is only performed on three out of eight floors of the building. 
Table 1. Investment for energy conservation activity in the Slamet Bratanata.

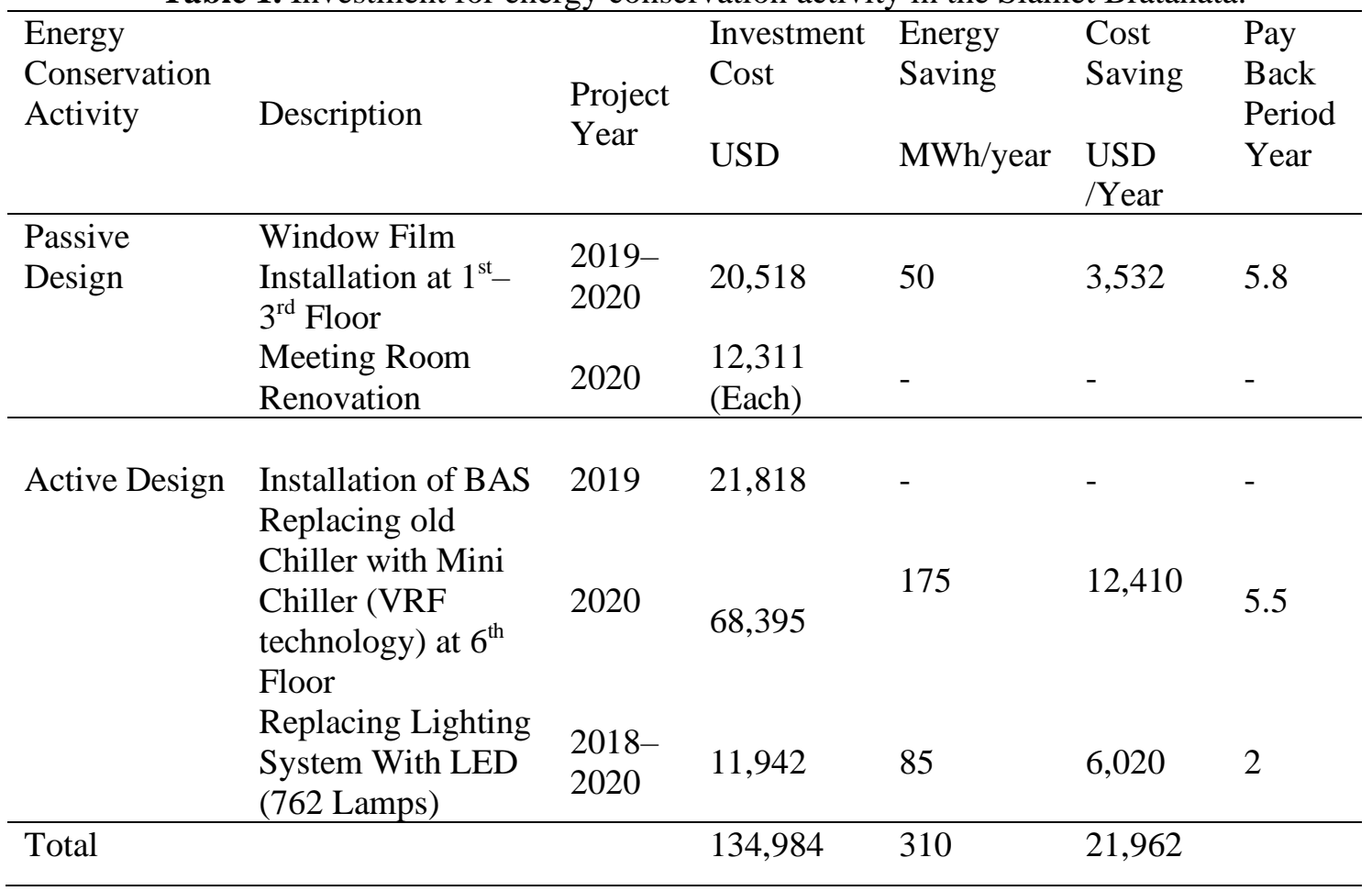

Concerning the active strategies, some technology has been implemented to improve energy efficiency performance as recommended in Table 1. It includes BAS installation, old chiller replacement, LED installation and meeting room renovation. Utilizing the building automation system, automated control and monitoring within a building can be performed. Building automation systems have been utilized massively due to its capability for shifting stand-alone systems into intelligent computerized communication technology-based solutions (Bhatt, 2019). The Slamet Bratanata has implemented an automation system in energy management in buildings, building automation systems. The automation system manages the use of electrical equipment on all floors of the building. Furthermore, control of the AC, lighting system and elevators can be done by the BAS Programming Logic Control system. In addition, building automation system technology is applied to monitor real-time energy consumption $(\mathrm{kWh})$ for equipment on each floor.

The main AC system in the Slamet Bratanata uses energy-efficient and environmentally-friendly equipment with VRF technology. Variable refrigerant flow systems can manage part-load energy performance, flexible control with relatively easy installation and maintenance (Zhang et al., 2019). Some additional split air conditioners are utilized with inverter technologies (EER $\geq 17$ BTU hour/Watt) using R-32 refrigerant. Furthermore, a high efficient mini chiller (COP 4) was installed in 2020 to replace the old one (COP 2.4). Chiller replacement has a significant impact on the energy efficiency improvement in the building with the relatively short payback periods (5.5 years), as indicated in Table 1. Therefore, currently, it is only deployed on the 6th floor. Further replacement on another floor can improve the building performance.

For the lighting, each room has been equipped with a TL-8 LED lamp. In certain locations, light intensity adjustable lamps are utilized. The motion sensors have been installed in all toilets and work areas of the staff for reducing energy consumption from lighting.

The role of smart technologies is crucially significant for sustainable energy utilization, including in the energy sector (Nižetić et al., 2019). One of the technologies adopted in the building sector is the Energy Monitoring System (EMonS). The system is employed in real-time and can be accessed via mobile phones to monitor the electricity usage of equipment on each floor. EMonS can also monitor energy use in all buildings of the Ministry of Energy and Mineral Resources (MEMR). The information 
obtained from EMonS is real-time energy usage and profile on each floor, reduction of greenhouse gas emissions from the saving, bill of electricity and energy efficiency index per day $\left(\mathrm{kWh} / \mathrm{m}^{2}\right)$.

The implementation of energy management has succeeded in reducing energy consumption by 613,188 $\mathrm{kWh} /$ year and energy efficiency index by $129.06 \mathrm{kWh} / \mathrm{m}^{2} /$ year in 2020 , as presented in Table 2 and Figure 4. Having the score, the energy efficiency index can be categorized as very efficient for an existing building of 27 years old. As a comparison, according to a survey, the office building in Indonesia has $160 \mathrm{kWh} / \mathrm{m}^{2} /$ year-202 $\mathrm{kWh} / \mathrm{m}^{2} /$ year energy efficiency index on average (EBTKE, 2019). As a part of the energy management cycle, the Energy Performance Indicator (EnPI) of the Slamet Bratanata has been monitored based on dependent variables, namely occupancy and cooling degree days. The particular activity is in line with ISO 50006 requirement. EnPI can measure energy savings objectively, excluding any abnormal factors such as the COVID-19 pandemic. Adopting such a rationalisation approach, energy-saving in 2020 is estimated at around $4.2 \%$ compared to the baseline.

Table 2. Energy savings 2018-2020.

\begin{tabular}{cllllll}
\hline \multirow{2}{*}{ Year } & \multirow{2}{*}{$\begin{array}{c}\text { Energy } \\
\text { Consumption }\end{array}$} & \multicolumn{2}{c}{ Occupancy } & $\begin{array}{l}\text { Cooling } \\
\text { Degree Days }\end{array}$ & Energy Baseline & \multicolumn{2}{c}{$\begin{array}{c}\text { Energy } \\
\text { Savings }\end{array}$} \\
\cline { 2 - 6 } & $\mathrm{kWh}$ & Man-hours & ${ }^{\circ} \mathrm{C}$ & $\mathrm{kWh}$ & $\mathrm{kWh}$ & $\%$ \\
\hline 2018 & $2,200,544$ & 619,375 & 1,556 & baseline period & - & - \\
2019 & $2,165,456$ & 632,425 & 1,538 & $2,215,056$ & 49,600 & 2.3 \\
2020 & $1,587,356$ & 274,550 & 1,459 & $1,653,777$ & 66,421 & 4.2 \\
\cline { 3 - 6 }
\end{tabular}

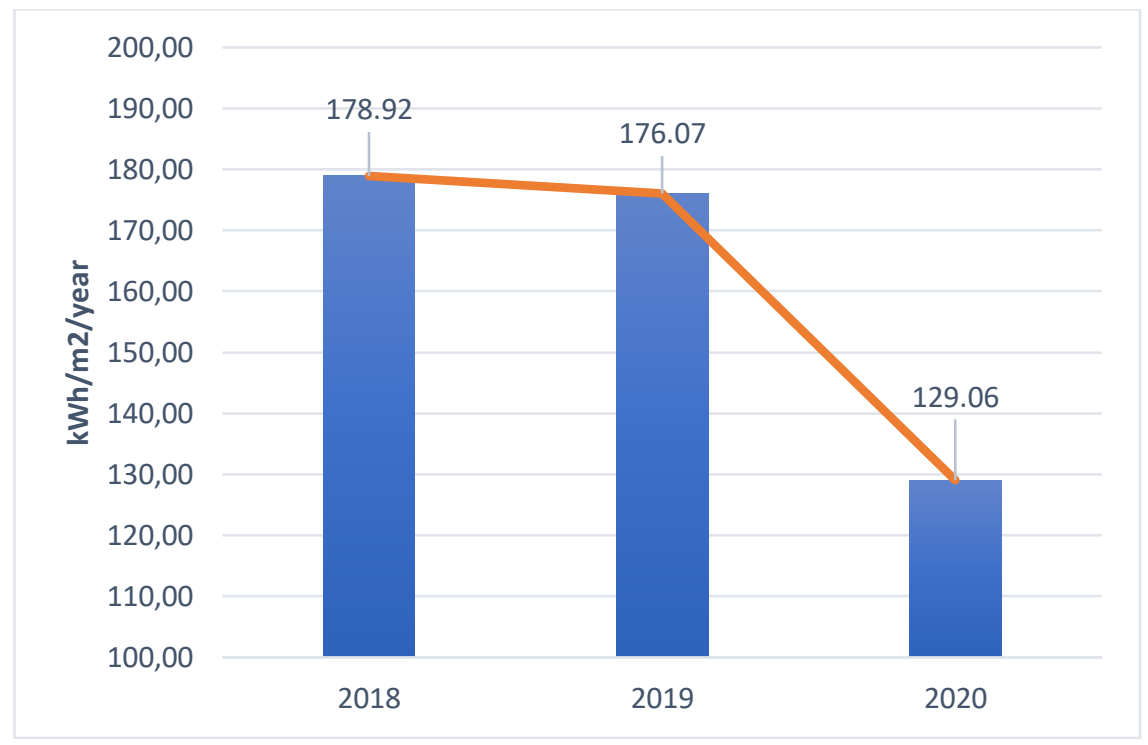

Figure 4. Energy efficiency index.

The environmental aspect of energy management was also measured, as indicated in Table 3 . With the implementation of ISO 50001:2018 Energy Management Systems, the calculation data are documented annually. Therefore, the calculation of GHG emission reduction has been included as a part of an effort to reducing GHG emissions nationally. The energy management activity in the Slamet Bratanata can reduce greenhouse gas emissions by 588,94 tons of $\mathrm{CO}_{2}$ equivalent. From the aftermentioned reduction number, most of it is related to the energy-saving activity. The proportion from renewable energy through PV rooftop is only contributed around 10\%. From a global perspective, the building sector represents almost a third of energy-related $\mathrm{CO}_{2}$ emissions (IEA, 2019). Having such contribution, achieving a more progressive emission reduction target, such as net zero-emission building in the object, will require a significant proportion from the renewable energy source. Therefore, further investigation 
concerning techno-economic feasibility for more renewable energy offsite/onsite contribution is required.

Table 3. Carbon emission reduction.

\begin{tabular}{llccc}
\hline No. & \multicolumn{1}{c}{ Description } & MWh/year & $\begin{array}{c}\text { Emission Factor } \\
\left(\mathrm{tCO}_{2} \text { eq/MWh }\right.\end{array}$ & $\begin{array}{c}\text { Carbon Emission } \\
\left(\mathrm{tCO}_{2} \mathrm{eq}\right)\end{array}$ \\
\hline A & Electricity from Grid (PT PLN) & & & \\
& $\begin{array}{l}\text { Electricity Savings 2019 } \\
\text { Electricity Savings 2020 }\end{array}$ & 35.08 & 0.88 & 30.88 \\
B. $\quad \begin{array}{l}\text { Electricity from Rooftop Photovoltaic } \\
\text { Electricity Production for Lighting } \\
\quad \text { \& A/C (Specific Area) }\end{array}$ & 56.10 & 0.88 & 508.72 \\
\hline & & & \\
\hline
\end{tabular}

*Indonesia Grid Emission Factor

\section{Conclusion}

Our study focuses on among the first Indonesian public building that has implemented an energy management system compliant with ISO 50001 standard. The objectives of the research are to describe the approach adopted for the energy management systems of the building, as well as highlighting the main aspects that determined this interesting and unique experience. To do so, we perform our analysis of the implementation of energy management in the building sector based on the ISO 50001 framework.

It is found that the management keeps a firm commitment for continuous improvement by creating an energy management structure and appointing an energy manager. To implement ISO 50001 Energy Management System in the building, the energy management team has held various activities. It includes developing standard operational procedure, working instruction and appointing a person in charge on each floor to oversee energy management activities. There is an energy efficiency competition called every two years to cultivate energy efficiency habits on each floor. As part of the part of energy management system cycle, an Investment Grade Audit was performed in 2018. Implementing the IGA recommendation, the passive and active energy-efficient technologies have been applied in the Slamet Bratanata. Active technologies that have been implemented include building automation system utilization, mini chiller installation, LED lighting and energy monitoring system application. Concerning the passive design, some of the floors in the building had been equipped with windows film and energy-efficient redesigned room space. The implementation of the energy management system has succeeded in reducing energy consumption by $613.188 \mathrm{kWh}$ (in 2018-2020) and Energy Efficiency Index by $129.06 \mathrm{kWh} / \mathrm{m} 2 /$ year in 2020 . In addition, the environmental aspect of energy management was also improved. Management energy implementation reduced greenhouse gas emissions by 588,94 tons of $\mathrm{CO}_{2}$ equivalent.

The finding of the study can contribute significantly to more effective energy management as a reference for the further desirable implementation of ISO 50001 Standard in similar public buildings as well as building sector contexts. Flourishing energy management applications in the building sector can trigger economic recovery as well as strengthening energy security improvement in the country.

For a future study, as a benchmark for the public building, it is necessary to investigate the building opportunity and challenge for a more progressive energy performance target, such as reaching net-zero energy building. Doing so, active/passive strategies, as well as renewable energy proportion, should be integrated for improving energy performance. Further low/high-cost energy measures can be studied, such as improving vegetation, utilizing double glass technology to minimize the heat, as well as onsite/offsite renewable energy contribution. 


$\begin{array}{lll}\text { Abbreviation } & \\ \text { DGNREEC } & : \text { Directorate General of New Renewable Energy and Energy Conservation } \\ \text { EEI } & : \text { Energy Efficiency Index } \\ \text { EER } & : \text { Energy Efficiency Rating } \\ \text { EMonS } & : \text { Energy Monitoring System } \\ \text { EnPI } & : \text { Energy Performance Indicator } \\ \text { GHG } & : \text { Greenhouse gas } \\ \text { IGA } & : \text { Investment Grade Audit } \\ \text { LED } & : \text { Light-Emitting Diode } \\ \text { MEMR } & : \text { Ministry of Energy and Mineral Resources } \\ \text { PLN } & : \text { Perusahaan Listrik Negara } \\ \text { PV } & : \text { Photovoltaic } \\ \text { SOP } & : \text { Standard Operational Procedure } \\ \text { TL } & : \text { Unbe Luminescent } \\ \text { UPS } & : \text { Variable Refrigerant Flow } \\ \text { VRF } & : \text { Working Instruction }\end{array}$

\section{References}

Bhatt, J. G. (2019). Building automation systems: Recent trends, design and development. Rapid Automation: Concepts, Methodologies, Tools, and Applications, 376-409.

EBTKE. (2019). Office Building. https://simebtke.esdm.go.id/sinergi/sektor pengguna energi/detail/18/gedung-perkantoran

Ferrari, S., Bruni, E., \& Bramonti, L. (2020). Effective implementation of ISO 50001: A case study on energy management for heating load reduction for a social building stock in Northern Italy. Energy and Buildings, 219, 110029.

Forster, P. M., Forster, H. I., Evans, M. J., Gidden, M. J., Jones, C. D., Keller, C. A., Lamboll, R. D., Le Quéré, C., Rogelj, J., \& Rosen, D. (2020). Current and future global climate impacts resulting from COVID-19. Nature Climate Change, 10(10), 913-919.

García-Sanz-Calcedo, J., Al-Kassir, A., \& Yusaf, T. (2018). Economic and environmental impact of energy saving in healthcare buildings. Applied Sciences, 8(3), 440.

Halimatussadiah, A., Widyasanti, A. A., Damayanti, A., Verico, K., Qibthiyyah, R. M., Kurniawan, R., Rezki, J. F., Rahardi, F., Sholihah, N. K., Budiantoro, S., Halimatussadiah, A., Cesarina, A., Siregar, A. A., Hanum, C., Wisana, D., Rahardi, F., Bintara, H., Rezki, J. F., Husna, M., ... Sofiyandi, Y. (2020). Thinking ahead: Indonesia's agenda on sustainable recovery from COVID -19 pandemic. LPEM.

Harkouss, F., Fardoun, F., \& Biwole, P. H. (2018). Passive design optimization of low energy buildings in different climates. Energy, 165, 591-613.

Hepburn, C., O'Callaghan, B., Stern, N., Stiglitz, J., \& Zenghelis, D. (2020). Will COVID-19 fiscal recovery packages accelerate or retard progress on climate change? Oxford Review of Economic Policy, 36.

Huang, E. G. T. (2011). Understanding the requirements of the energy management system certification: A discussion about the challenges, impacts and opportunities for energy efficiency (Issue July, p. 16). SGS.

IEA. (2019). The critical role of buildings. https://www.iea.org/reports/the-critical-role-of-buildings

IEA. (2021). Net zero by 2050: A roadmap for the global energy sector.

Jia, M., Srinivasan, R. S., \& Raheem, A. A. (2017). From occupancy to occupant behavior: An analytical survey of data acquisition technologies, modeling methodologies and simulation 
coupling mechanisms for building energy efficiency. Renewable and Sustainable Energy Reviews, $68,525-540$.

Kurniawan, R., Trencher, G. P., Edianto, A. S., Setiawan, I. E., \& Matsubae, K. (2020). Understanding the multi-faceted drivers of increasing coal consumption in Indonesia. Energies, 13(14), 1-22. https://doi.org/10.3390/en13143660

Ma, M., Cai, W., \& Wu, Y. (2019). China act on the energy efficiency of civil buildings (2008): A decade review. Science of The Total Environment, 651, 42-60.

Mardiana, D. A., Kartoatmodjo, R. S. T., \& Kasmungin, S. (2018). Estimation of Indonesia's energy demand to 2030 and alternatives scenario to reduce oil dependence. Indonesian Journal of Energy, $1(2), 32-45$.

Molina-Solana, M., Ros, M., Ruiz, M. D., Gómez-Romero, J., \& Martín-Bautista, M. J. (2017). Data science for building energy management: A review. Renewable and Sustainable Energy Reviews, 70, 598-609.

Nižetić, S., Djilali, N., Papadopoulos, A., \& Rodrigues, J. J. P. C. (2019). Smart technologies for promotion of energy efficiency, utilization of sustainable resources and waste management. Journal of Cleaner Production, 231, 565-591.

Purnomo Yusgiantoro Center. (2021). Primary Energy Supply. https://datacenterpyc.org/data/statistics/energy-balance/primary-energy-supply/

Selvakkumaran, S., \& Limmeechokchai, B. (2013). Energy security and co-benefits of energy efficiency improvement in three Asian countries. Renewable and Sustainable Energy Reviews, 20, 491-503.

SGS. (2017). ISO 50001: 2018 Readiness checklist. White Paper, 1-12. SGS. https://www.sgs.com/

Shaikh, P. H., Nor, N. B. M., Sahito, A. A., Nallagownden, P., Elamvazuthi, I., \& Shaikh, M. S. (2017). Building energy for sustainable development in Malaysia: A review. Renewable and Sustainable Energy Reviews, 75, 1392-1403.

Sun, X., Gou, Z., \& Lau, S. S.-Y. (2018). Cost-effectiveness of active and passive design strategies for existing building retrofits in tropical climate: Case study of a zero energy building. Journal of Cleaner Production, 183, 35-45.

Trotta, G. (2020). Assessing energy efficiency improvements and related energy security and climate benefits in Finland: An ex post multi-sectoral decomposition analysis. Energy Economics, 86, 104640.

Zhang, G., Xiao, H., Zhang, P., Wang, B., Li, X., Shi, W., \& Cao, Y. (2019). Review on recent developments of variable refrigerant flow systems since 2015. Energy and Buildings, 198, 444466.

Zheng, S., Lam, C.-M., Hsu, S.-C., \& Ren, J. (2018). Evaluating efficiency of energy conservation measures in energy service companies in China. Energy Policy, 122, 580-591.

Zhou, N., Khanna, N., Feng, W., Ke, J., \& Levine, M. (2018). Scenarios of energy efficiency and CO2 emissions reduction potential in the buildings sector in China to year 2050. Nature Energy, 3(11), 978-984. 